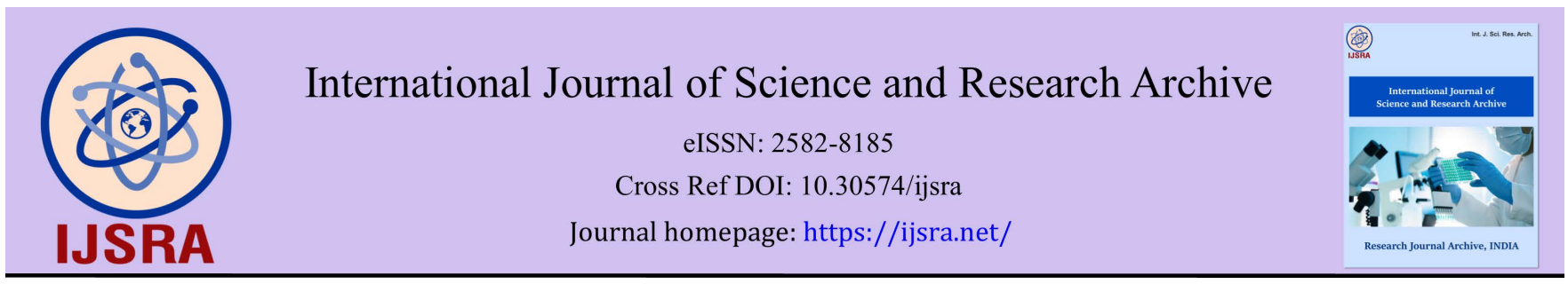

(RESEARCH ARTICLE)

\title{
Mobbing, organizational trust, voice and deviance behaviour among environmental health and safety professionals in Nigeria
}

\author{
Yahya Saleh Ibrahim ${ }^{1, *}$, Aishatu Abdullahi Na'ibi ${ }^{2}$ and Suleiman Usman ${ }^{3}$ \\ ${ }^{1}$ Centre for Energy \& Environmental Sustainability Research (CEESR) Kaduna State University-Kaduna-Nigeria. \\ ${ }^{2}$ Department of Hospitality Management, Kaduna Polytechnic-Kaduna-Nigeria. \\ ${ }^{3}$ Department of Environmental Health Science, Shehu Idris College of Environmental Health Technology Makarfi-Kaduna \\ State Nigeria.
}

International Journal of Science and Research Archive, 2021, 02(02), 194-205

Publication history: Received on 07 April 2021; revised on 16 May 2021; accepted on 21 May 2021

Article DOI: https://doi.org/10.30574/ijsra.2021.2.2.0066

\begin{abstract}
This paper aims at assessing the present circumstances strongly associated with healthcare workers in Nigeria. Particular reference is to the recognition of the fact that mobbing and/or bullying stressors are being meted on environmental health workers by other medical and paramedical workers in the field in Nigeria. The study used environmental health workers as sampled population as well includes different actors from the healthcare work force to identify certain key elements associated with mobbing and/or bullying in a set of job-related organizational contexts. The data were obtained using an adopted questionnaire used by previous researchers. In line with this topic three objectives were developed Mobbing and Organizational Trusts, Mobbing and Voice Behaviour, Mobbing and Deviance behaviour. The total number of questionnaires distributed was 220 out of which 200 were dully filled and return for analysis. The results indicated that there is significant relationship between environmental health workers precisely working in the primary, secondary and tertiary healthcare being mobbed or bullied. The identified scene for such act has been identified to be when patients or guest are present in the facility where they work, at meetings or work briefing and during special area inspections. Worst still, was the non-inclusion of environmental health workers in the scheme of building plan, supervision, approval and smooth handing over of projects after completion for lifecycle inspection. The act tends to discourage their job performance and increase the prevalence of diseases related to environmental factors and conditions in the country. Chances are that an environmental health worker may be bullied if the officer insisted on inspecting sites where other professionals (Civil, mechanical, electrical, architects, surveyors amongst other) are in charge during construction. These led to the environmental health workers to suffer from psycho-industrial ailments or work stress, enjoy little satisfaction from their working conditions, and failed to perceive opportunities for promotions in their organizations and future progression in the profession. The implications of these findings could assist in reassuring environmental health workers enviable future, greater challenges and hopes, reduction IN environmentally driven diseases, policy recognition and medical family reintegration by facilitating, good social professional relationships among healthcare workers in the country.
\end{abstract}

Keywords: Bullying; Mobbing; Voice Behaviour; Deviance Behavior; Organizational Citizenship

\section{Introduction}

Mobbing or Bullying is defined as psychological violence or mobbing as hostile behaviors and uncultured communication, directed stylishly by a leader, colleague, a personality or more individuals, toward an individual or group of individuals (Yildirim, \& Yildrim, 2009). Mobbing at workplace has destructive effects on individual as well as

\footnotetext{
${ }^{*}$ Corresponding author: Yahya Saleh Ibrahim

Director Centre for Energy \& Environmental Strategy Research (CEESR) Kaduna State University- Tafawa Balewa Way, Unguwan Rimi-Kaduna-Nigeria..
}

Copyright (C) 2021 Author(s) retain the copyright of this article. This article is published under the terms of the Creative Commons Attribution Liscense 4.0. 
on organization (Ekici \& Beder, 2014). This therefore, shows that psychological violence experienced by employees traced back some decades now since the beginning of working life, whose appearance is avoided, and sometime even ignored, adversely influences organizational and employees, voice behaviour, organizational citizenship, organizational deviance behaviour, organizational culture and justice perception (Kose \& Yildirim, 2013; Hutchinson et al., 2010; Liljegren \& Ekberg, 2009). There has been wide spread distractions associated with the functions and role of environmental health officers especially in Nigeria. The distraction came in the form of discrediting and mobbing by colleagues in the profession, these leads to Environmental Health Officers (EHO's) experience of mobbing with seemingly an engendering lack of voice behaviour, absence of organizational citizenship and transmuted deviance behaviour (Hansen, Hogh, Persson, Karlson, Gadre, Orbeak, 2006). Looking forward became eminent to avert the negative effects of workplace bullying on both individuals and organizations (Antonio, Muniz, José and Araque-Padilla, 2013). Mobbing has been established to have negative impacts on managerial costs and turnover escalation and productivity declines (Gumbus \& Lyons, 2011). The more the number of those employees witnessing mobbing distractions, the more they experience negative emotional and physical health condition (Anjum, Yasmeen,.Yasmeen, 2011). Some of the recorded negative effects includes reduction in the quality of work, negative impacts on the organization's reputation, the escalation of mistakes and absenteeism, and the corrosion of customer relationships due to lack of attention paid to their objectives and commitments, among others (Razzaghian, \& Shah, 2011).This assertion becomes even more significant for those organizations mainly composed of employees providing particular or welfare related assistance in a close and direct way to patients precisely the healthcare workers (Gumbulus \& Lyon, 2011).

Mobbing or bullying is an organizational behaviour that is today recognize as fundamentally an occupational hazards in most working places and organizations. Certain professions suffered mobbing this is in addition to its presentation in the form of racism, gender derived, ethnically instituted and religiously encapsulated. Mobbing has divergent approach and appearance today. But the concern of this research is to uncover the specific mobbing and bullying meted on environmental health officers in Nigeria.

\section{Literature Review}

The environmental officers role, though primary in nature in medical practices but functionally important in the early detection and prevention of widespread primary or communicable diseases associated with environmental factors (Visile \& Yildrim, 2017; Einarsen, Hoel, Zapf, Cooper, 2003). The effort to determine the environmental officers position as healthcare professionals' exposed to mobbing behaviors and the relation of mobbing with voice behaviour, deviance behaviour or simply put in the new concept in occupational health and safety studies 'organizational misbehaviour' and organizational citizenship requires fundamental inquiry (Teymourzadeh, Rashidian, Arab, Akb ari-Sari, Hakimzadeh, 2014). In a study conducted by Visile \& Yildrim, (2017) in Minnesota with a total sampling frame of 897 healthcare professionals, though about 715 subjects were contacted and 479 respondents participated and as well completed the questionnaires for the study. Using Mobbing Behaviors Scale, prepared by Minnesota Satisfaction Questionnaire, and Organizational Commitment Scale shows an average age of the participants to be $37.3 \pm 8.3$ years; of the participants, $77 \%$ were female and $72.7 \%$ were nurses. The research also presented a rate of exposure to one of the sub-dimensions of mobbing scale at least once in the last year standing as $66.4 \%$ for isolation, $71.8 \%$ for attack on professional status, $78.1 \%$ for attack on personality, and $28.4 \%$ for direct negative behaviors. The research also revealed that Females as compared with males and participants with low income as compared to high income were more exposed to mobbing (Einarsen, Matthiesen, Skogstad, 1998). Research had shown that the strikingly important medical personnel or paramedical personnel like nurses, environmental health officers and community health officers as compared with doctors were more exposed to mobbing when compared just like employees with occupational experience of $>10$ years were more exposed to mobbing (Einarsen, Matthiesen, Skogstad, 1998).Various researches also revealed that exposure to mobbing were negatively correlated with external and general job satisfaction (Di Martino, 2002; El-Gilany, ElWehady, Amr, 2010). Other studies also revealed that attacks on personality and direct negative behaviors subdimensions were negatively correlated with internal satisfaction (Davenport, Schwartz, Elliott, 1999; Ferrinho, Biscaia, Fronteira, Craveiro, Antunes, Conceição, Flores, Santos, 2003). The potentiality of paramedical staff to be isolated in the clinical operations and medical practices despite their experiences and humulity, indirect attacks aside direct attacks on personality, and direct negative behaviors were positively correlated with the officer's commitment to their job (Cowie, Naylor, Rivers, Smith, Pereira, 2002). Another study concludes that the rate of exposure to mobbing was quite high among healthcare professionals. Study conducted by Visile and Yildrim, (2017), shows that though being satisfied with job is lower among those officers mobbed; commitment to the organization was not extraordinarily affected much.

Research conducted by Hogh, Hoel, and Carneiro (2011) investigates the effects of bullying on turnover and organizational voice behaviour among targets of bullying at work in an organization, the results confirmed that employee's exposure to bullying are most times associated with the decision to leave their workplaces. Though the absence of window to ventilate or fear of what will happen if such proclamations are made makes uncertain to what extent and reason that made such employees to actually leave (Hogh et al. 2011). The study uses questionnaire 
instrument to collect data among Danish healthcare workers as at the time of graduation, (Hogh, 2011). A total of 2154 respondents participated in the research. The results of the research conducted by Hogh, Hoel \& Carneiro, (2011),shows that, the first year after graduation, 9.2\% paramedical professionals reported being bullied at work, $1.8 \%$ frequently. Follow-up analyses showed a strong relationship between exposure to bullying, lack of voice, absence of organizational citizenship and turnover. The inclusion of push factors such as low social support and low sense of community, intention to leave and ill health did not change the relation between bullying, absence of voice, OCB and turnover significantly. Three reasons for quitting stood out among reasons given by the bullied respondents: poor leadership (lack of voice), being exposed to negative behaviour and health problems for frequently bullied (Hogh, et.al. 2011). In another study it was concluded that bullying may be costly to an organization in terms of staff turnover and subsequent recruitment and training of replacements.

Carnero, Martínez, \& Sa'nchez-Mangas, (2012) alludes that health challenges are significantly higher among mobbed workers compared to those employees that are not mobbed. This is true, when the health indicator is based on the employee's perception, not taking into account the obscured nature of mobbing leads to underestimation of its effect on health. As a category of bullying, mobbing is a form of violence in the workplace that damages the employing organization as well as the targeted employee (Myrian, Rene and Franciska, 2016). Overall prevalence of mobbing in healthcare setting is estimated at 4\% in most organizations (Ayranci, Yenilmez, Balci, Kaptanoglu, 2006; Di Martino, 2002). Another study revealed that, very few studies have explored mobbing among long-term care workers (El-Gilany, A. H., El-Wehady, A., Amr, M. 2010). Most studies examining the frequency of mobbing among nursing homes and its relationships with care workers' (i.e. registered nurse, licensed practical nurse, assistant nurse, nurse aide) health status, job satisfaction, and intention to leave, and to explore the work environment as a contributing factor to mobbing (Figueiredo-Ferraz, Gil-Monte1, Olivares-Faúndez, 2015).

Certain factors were considered as the major factors that causes mobbing, isues such as destructive acts, dictatorial acts, and as well as autocratic leadership by heads of healthcare units and departments (Fernando, Feijó, Gräf, Pearce, \& Fassa, 2019). There are other factors identified as causative factors as well which are strongly related to higher occurrence of bullying (Boyle, Koritsas, Coles, Stanley, 2007). On the other hand, supportive leadership style reduced mobbing, improves voice behaviour and organizational citizenship behaviour and reduced organizational deviance (Canbaz, Dundar, Dabak, Sunter, Peksen, Cetinoglu, 2008). Lack of consideration from the leaders to the individual employee's voice behaviour to ventilate to the leaders or before leaders or to the leaders also aggravates bullying or mobbing in the work place (Bilgel, Aytac, Bayram, 2006). Transformational and transactional leadership was able to reduce the intensity of mobbing and or bullying in clinical and healthcare related working environment (Aytac, Bozkurt, Bayram, Yildiz, Aytac, Akinci, Bilgel, 2011). Second to solving mobbing in clinical environment is associated with mobbing and bullying is the persistence of an authentic leadership and fair leadership as well has the capacity to reduced up to $70 \%$ the risk of bullying/mobbing among environmental health professionals (Picakciefe, Acar, Ibrahim Kilic, 2017). Another study confirmed that, worse physical and mental health increased the risk of being bullied both in cross-sectional and longitudinal analyses (Yaldrim \& Yaldrim, 2019). Those workers with tendency to seek for sick leave and being on sickness treatment were also positively associated with bullying (Carnero, Martínez, and Sa'nchezMangas,

\section{Operationalization of the Variables and Development of Hypothesis}

There are three basic hypothesis develop for the sake of this study. The study analysis the variables relationship thus: Mobbing and organizational trusts, Mobbing and voice behaviour and finally Mobbing and organizational deviance behaviour.

\subsection{Voice Behaviour}

\subsubsection{H $H_{1}$ there is significant positive effects of mobbing on EHO's Voice Behaviour in Nigeria}

Voice behaviour is one of the variables tested in this study. Voice behaviour has direct relationship with good and responsible leadership that will provide an opportunity for staff to express themselves and for their view to be respected. The study on mobbing and voice behaviour reveals that linking authentic leadership with staff nurses' trust in their manager, work engagement, voice behaviour and perceived unit care quality revealed a positive correlation (Branch, Ramsay, \& Barke 2012). In another study it shows that an authentic leadership is prelude to having an instrument that builds trust and healthier work environments (Kirel, 2007). Authentic leadership give special attention to honesty, integrity and high ethical standards in the development of leader-follower relationships (Anjum, Yasmeen, Yasmeen, 2011).The results of the study conducted by Razzaghian, \& Shah, (2011) suggests that authentic leadership and trust in the manager play a role in fostering trust, work engagement, voice behaviour and perceived quality of care. 
The results also suggested that improving and changing leadership and perceptions among healthcare practitioners can improve care quality and workplace conditions (Ariza-Montes,. Muniz, Montero-Simó, and Araque-Padilla 2013). It can as well facilitates genuine and positive relationships with their staff (Myriam, Schwendimann, Zuniga, 2016).

\subsection{Mobbing and Organizational Work Deviance Behaviour}

\subsection{1. $\mathrm{H}_{2}$ there is significant positive effects of mobbing on EHO's Organizational Work Deviance Behaviour in Nigeria}

Research into workplace bullying has continued to grow and mature since emerging from Scandinavian investigations into school bullying in the late 1970s. Research communities now exist well beyond Scandinavia, including Europe, the UK, Australia, Asia and the USA (Razzaghian, \& Shah, 2011). While the terms 'harassment' and 'mobbing' are often used to describe bullying behaviour, 'workplace bullying' tends to be the most consistently used term throughout the research community (Anjum, Yasmeen, Yasmeen, 2011). In the past two decades especially, researchers have made considerable advances in developing conceptual clarity, frameworks and theoretical explanations that help explain and address this very complex, but often oversimplified and misunderstood, phenomenon (Myriam, Schwendimann, Zuniga, 2016). Indeed, as a phenomenon, workplace bullying is now better understood with reasonably consistent research findings in relation to its prevalence; its negative effects on targets, bystanders and organizational effectiveness; and some of its likely antecedents (Kidwell \& Martin, 2005). However, as highlighted in this review, many challenges remain, particularly in relation to its theoretical foundations and efficacy of prevention and management strategies Bennett and Robinson (2000). Gaps in the literature and future research directions are discussed, including the vexing problem of developing an agreed definition of workplace bullying among the research community, the emergence of cyberbullying, the importance of bystanders in addressing the phenomenon and the use of both formal and informal approaches to prevention and intervention (Bennett and Robinson 2000).

\subsection{2. $H_{1}$ there is significant positive effects of mobbing on EHO's Organizational Trusts in Nigeria}

A complex phenomenon that characterizes life in organizations is the manifestation of behaviors that betrays the cordial relationship between employee and organization (Sackett, 2000). In the organizational literature, scholars and practitioners refer to these events as deviant behaviors or absence of organizational trusts in the workplace (Bernette and Robinson, 2000). Lack of organizational trusts can leads to deviant behaviors in the workplace which can generally be defined as an employee's behaviors in the work context that harm an organization and its legitimate interests (Sackett, 2002). The escalation of absence of Organizational Trusts (OT) in the Workplace can leads to deviant behavior (WDB) may include a variety of forms, from minor to severe issues and acts such as fraud, problem-making, low performance, misuse of organization time, web surfing during office hours, theft, aggression, drug abuse, and various types of mobbing and harassment (Kidwell \& Martin, 2005). Bennett and Robinson (2000) emphasized that WDB can be divided into two main categories according to its targets: behaviors that target other individuals (WDB-I), and behaviors targeting the organization (WDB-0). The first category, WDB-I, comprises deviant behaviors such as playing pranks on others, acting rudely, gossiping; the second category, WDB-0, comprises deviant behaviors such as stealing from the firm and sabotaging its materials/supplies, equipment or property. Therefore there is positive relationship between OT and WDB in the work place.

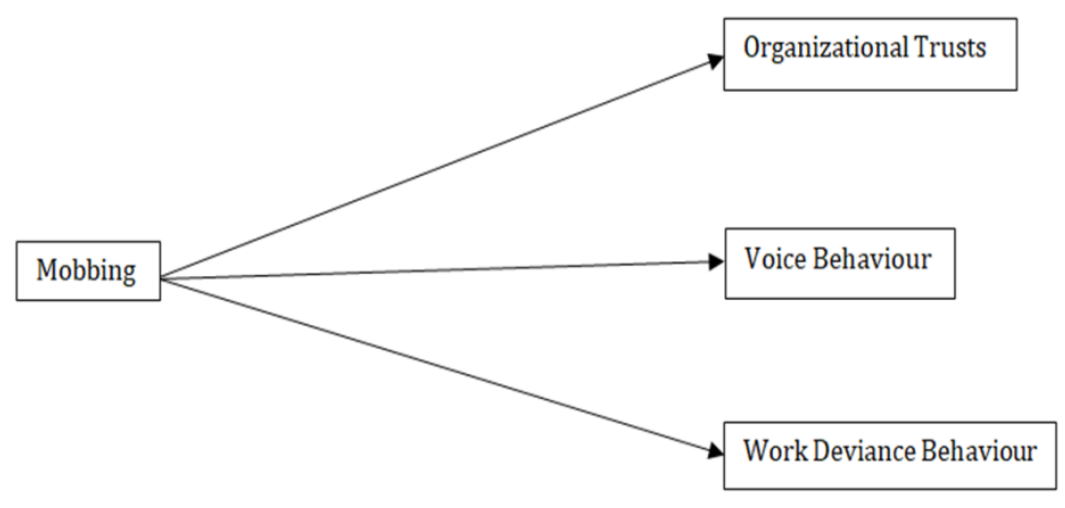

Figure 1 Conceptual Model of the Study 


\section{Methodology}

There are two generic setting in selecting the design of a study, I. e qualitative and quantitative approach and mixed method qualitative/quantitative approach of conducting a research. By virtue of the research questions and variable of this research as well as previous research on the topic of this study, the approach selected was quantitative because of the multiplicity of the respondents and nature of the issue under investigation.

\subsection{Population of the study}

The population of this study comprises of Environmental Health Officers employed in Kaduna state local governments, hospitals and clinics, institutional as well those working in the industries. A total number of 244 employees were contacted as an assumed sampling frame out of which 221 were selected and were given the questionnaires to respond. The employees that responded to the questionnaire work in various organizations and sections mentioned above.

\subsection{Sample size estimation}

This was estimated using the formula for calculating sample size when studying population greater than 10,000

$$
n=\frac{Z^{2} p q}{d^{2}}
$$

Where:

$\mathrm{n}=$ Sample size.

$\mathrm{Z}=$ Standard deviation usually set at 1.96 which corresponds to $95 \%$ confidence interval.

$\mathrm{P}=$ the proportion in the target population estimated to have a particular characteristics.

$50 \%$ will be used as there is no study known to the researcher that shows the influence of a hotel workers satisfaction.

$\mathrm{P}=0.5$

$\mathrm{q}=1.0-\mathrm{p}=1.0-0.50=0.50$

$\mathrm{d}=$ the degree of accuracy desired usually set at 0.05 . Therefore,

$$
n=\frac{(1.96)^{2}(0.5)(0.5)}{(0.05)^{2}}
$$

$n=384$

Since the estimated population over the study period is less than 10,000 , the following formula was applied.

$$
\mathrm{nf}=\frac{\mathrm{n}}{1+(\mathrm{n}) /(\mathrm{N})}
$$

Where

$\mathrm{nf}=$ The desired sample size when the population is less than 10,000

$\mathrm{n}=$ the desired sample size when the population is more than 10,000

$\mathrm{N}=$ Total population to be considered.

\subsection{Instrument}

The current study adapted items from various studies to measure the variables in the model of the study, Hence, 5 items from prior study measure employee Mobbing. As for Organizational Trusts, five items were used for its measurement, 
five items were used to measure Voice behaviour and work deviance behaviour had five items. Strong Cronbach Alpha and wide usage of the item in the respective studies justified the adaption of such items from the various studies mentioned in the literature and statement of problem section. All the variables and their respective items and sources of the measurement feasibly responded to research analysis. All the variables in questionnaire were measured on a fivepoint Likert scale ranging from strongly agree to strongly disagree, anchored from 1to 5 (Likert,1932).

\subsection{Validity of the Instrument}

To ensure validity of the instrument, content validity was conducted by consulting three experts of research in the related area to assess the appropriateness of the instrument. The consultations led to removal and reshaping of some items to make the instrument simpler to the respondents and more appropriate to measure the variables, the respondents spends 10-15 minutes to fill capping it as simple to fill instrument. The improved version was administered for the survey.

\subsection{Data Collection Procedure}

This study used self-administered approach to collect data from the respondents in this approach; the respondents are expected to complete the questions either in the presence of the researcher or in his absence (Zikmund, Babin, Carr, \& Griffin, 2013). This approach is suitable for a survey restricted to a local area; makes data collection faster; allow for elucidation by the researcher; and has likelihood of high rate of response (Sekaran\& Bougie, 2010).

\subsection{Data Analysis}

Having completed the data collection, the data collected were subjected to preliminary analysis before the main or final analysis. Preliminary analysis certified that data meets the requirements for inferential analysis; preliminary checking of data is essential prior to inferential analysis and it help the researcher to better understand the data (Hair, Black, Bibin, \& Anderson, 20110). The statistical package for social science (SPSS) was used for the preliminary analysis.

\section{Results}

In this section, analysis of all data collected from the questionnaires is presented in tables and charts to show frequencies and percentages of the respondents as well the results of the inferential analysis i.e. (Chi-square $\mathrm{X}^{2}$ results).

\subsection{Demographic Characteristics of the Respondents}

The study sample comprised of 221 respondents from some selected hotels in Nigeria. Out of the total questionnaires distributed 200 were returned as complete and were used to represents the total sample in this analysis. This shows that only 21 questionnaires were either not returned or not completed correctly or fully and are declared unfit for analysis. Considering the fact that the 21 uncompleted or not returned questionnaires cannot invalidate the results the analysis was done using the accredited 200 questionnaires for this result.

Table 1 displays the descriptive statistics for the sample study. The age of the respondents shows $30.5 \%$ are within the age bracket of $18-27$ years of age, while 33\% represents the ages of $28-37$, ages $38-47$ are represented by $29.5 \%$ and the least age bracket is $48-57$ with 7\%. This signifies the employees are majority within the age of 28-37 years with $33 \%$, implying that those working are strategically matured.

Table 1 Age group of respondent

\begin{tabular}{|l|l|l|}
\hline Age Group & Frequency & Percent [\%] \\
\hline 18-27 years & 61 & 30.5 \\
\hline 28-37 years & 66 & 33.0 \\
\hline 38-47 years & 59 & 29.5 \\
\hline 48-57 years & 14 & 7.0 \\
\hline 58 and Above & 0 & 0 \\
\hline Total & 200 & 100.0 \\
\hline
\end{tabular}


Table 2 shows that out of the 200 respondents' females have the highest number with $55 \%$ of the total population of the employees in the industry. While the male respondents constituted $45 \%$ of the total distribution. This implies that there was more female working as EHO's than the male employees in the state. This may be attributable to the kind of educational system we are operating where paramedical/hospital management in Nigeria predominated by females and the job in itself is classified culturally as female profession especially in northern part of the country.

Table 2 Gender of the respondents

\begin{tabular}{|l|l|l|}
\hline Gender & Frequency & Percent[\%] \\
\hline Male & 90 & 45.0 \\
\hline Female & 110 & 55.0 \\
\hline Total & 200 & 100.0 \\
\hline
\end{tabular}

The result on table 3 shows that those with the highest percentage are those with less than one year working experience with 38\% distribution, signaling that those with higher working experience hardly stays because of the emerging challenges associated with mobbing in Nigeria. The change in government that reduce wasteful expenses as well supported primary healthcare promotion in the state may support the grievances of the EHO's. 4.0\% of the respondents had work for 6-10 Years, while those that work for the period between 1-5 years were represented by $19.0 \%$ of the distribution, respondents who had worked within $11-15$ years, had $36.0 \%$ and $3.0 \%$ represents workers with $16-20$ years. This implies that majority of the EHO's have less than 1 year working experience.

Table 3 Working experience of respondents

\begin{tabular}{|l|l|l|}
\hline Working Experience & Frequency & Percent[\%] \\
\hline Under 1 year & 76 & 38.0 \\
\hline 1-5 years & 38 & 19.0 \\
\hline 6-10 years & 8 & 4.0 \\
\hline 11-15 years & 72 & 36.0 \\
\hline 16-20 years & 6 & 3.0 \\
\hline Total & 200 & 100.0 \\
\hline
\end{tabular}

The table 4 shows that $40.5 \%$ of the respondents are married, while the Single or Divorced respondents constituted $59.5 \%$ of the distribution. This implies that there were more single or divorced than the married respondents.

Table 4 Marital status of respondents

\begin{tabular}{|l|l|l|}
\hline Marital Status & Frequency & Percent [\%] \\
\hline Single or divorced & 119 & 59.5 \\
\hline Married & 81 & 40.5 \\
\hline Total & 200 & 100.0 \\
\hline
\end{tabular}

\subsection{Reliability Analysis}

Based on the results of the analysis carried out represented in table 4.9 it was revealed that the cronbach Alpha value $(0.760)$ shows that the instrument use in the analysis are sufficient since the cronbach Alpha value stood at ( 0.760$)$ is greater than (0.6). However 6 items were considered in the research in order to determine respondent mobbing in their work places details as depicted on table 5 . 
Table 5 Reliability statistics

\begin{tabular}{|l|l|l|}
\hline Cronbach Alpha & Cronbach Alpha Based on Standardized Items & N of Items \\
\hline 0.760 & 0.751 & 6 \\
\hline
\end{tabular}

\subsubsection{Ho There is significant relationship between Mobbing and Trust in Organization among EHO's in Nigerian}

The result on the table 6 , shows that $\mathrm{x}^{2}(544)=1351.6, \rho=0.000$. This indicates that there is significant relationship between mobbing and trust in organization. The higher the trust the organization placed on employees the more likely for mobbing not to thrive in such organization.

Table 6 Chi-Square tests between mobbing and trust in organization

\begin{tabular}{|l|l|l|l|}
\hline & Value & Df & Asymp. Sig. (2-sided) \\
\hline Pearson Chi-Square & $1351.685(\mathrm{a})$ & 544 & 0.000 \\
\hline Likelihood Ratio & 585.996 & 544 & 0.103 \\
\hline Linear-by-Linear Association & 1.972 & 1 & 0.160 \\
\hline N of Valid Cases & 200 & & \\
\hline \multicolumn{2}{|l|}{ a 592 cells (99.7\%) have expected count less than 5. The minimum expected count is.01. }
\end{tabular}

5.2.2. Ho There is significant relationship between Mobbing and Voice Behaviour among EHO's in Nigerian hotel industry

The result on the table 7 representing mobbing and voice behaviour in the work place, shows that $x^{2}(544)=1273.6, \rho$ $=0.000$. This indicates that there is significant relationship between mobbing and voice behavior. Given the chance and opportunity to voice out opinion has significant role in creating an enabling environment for self-respect feeling of job satisfaction and reduction in mobbed attitude. This suggests that an improvement in voice behavior increases professional exchange of ideas and better service to humanity.

Table 7 Chi-Square tests between mobbing and voice behavior among EHO's

\begin{tabular}{|l|l|l|l|}
\hline & Value & Df & Asymp. Sig. (2-sided) \\
\hline Pearson Chi-Square & $1273.678(\mathrm{a})$ & 544 & 0.000 \\
\hline Likelihood Ratio & 655.000 & 544 & 0.001 \\
\hline Linear-by-Linear Association & 18.111 & 1 & 0.000 \\
\hline N of Valid Cases & 200 & & \\
\hline \multicolumn{2}{|l|}{ a 593 cells (99.8\%) have expected count less than 5. The minimum expected count is .01. }
\end{tabular}

5.2.3. Ho There is no significant relationship between Mobbing and work deviance among EHO's in Nigerian

Table 8 Chi-Square Tests between mobbing and Work Deviance

\begin{tabular}{|l|l|l|l|}
\hline & Value & Df & Asymp. Sig. (2-sided) \\
\hline Pearson Chi-Square & $1814.071(\mathrm{a})$ & 704 & 0.000 \\
\hline Likelihood Ratio & 718.382 & 704 & 0.345 \\
\hline Linear-by-Linear Association & 2.207 & 1 & 0.137 \\
\hline N of Valid Cases & 200 & \multicolumn{2}{l|}{} \\
\hline \multicolumn{2}{|l|}{ a 759 cells (100.0\%) have expected count less than 5. The minimum expected count is.01 }
\end{tabular}


The result on table 8 , shows that $\mathrm{x}^{2}(704)=1814.0, \rho=0.000$. This indicates that there is a significant relationship between mobbing and work deviance. Deviance at work in Nigerian hospitals and care giving jobs has direct and significant relationship with bullying and/or mobbing which discourages lack of satisfaction and deviance behaviour.

\section{Discussion}

The results diagnosed the effects of mobbing as a safety challenge in our various working environments or settings. Mobbing by this study has direct positive impact and effects on employee tendency to lost trusts in the organization with a Chi-Square results showing $\rho=0.000$ which is less than 0.005 representing an influence that could affect performance in the working place by having less trusts and believing that the job has no promising future for the employee in this case the EHO's. The persistence and the doggedness of the practitioners to resists all mobbing by colleagues makes environmental health profession to thrive today in Nigeria. Mobbing as organizational misbehavior needs to give way to collaborative working environment which will engender trusts in the profession and promotes better health education and health environment for both the mobbee and the mobbed. The results of the second hypothesis study the relationship between mobbing and voice behaviour in an organization. The results also recognize the fact that among health or paramedical practitioners the most mobbed category are the environmental health officers compared to nursing, community and public health cadres. In the clinical practices EHO's is not allow to partake in operations despite his level of experience and the practicum experience they had together with other paramedical cadres. The irony remains that EHO's are responsible for the inspection of the clinical environment and general hygiene of all hospital environment as special areas. The results of Chi-square analysis shows that, $\mathrm{x}^{2}(544)=1273.6, \rho=0.000$, there is significant relationship between mobbing and voice behaviour with the chi-square value as 0.000 less than 0.005. It then mean that, the more the mobbing behaviour being meted on EHO's the more likelihood for their loss of their voice to decide on the progress of their job and invariably it mean more environmentally related diseases and impairment for women, children and the vulnerable that are living in such environments. This would translate into more childbirth defects, more maternal motility and sudden death syndrome among younger women per birth in the hospital and general environment. Finally the hypothesis testing the relationship between mobbing and work deviance behaviour (WDB) shows significant intertwining relationship, with mobbing causing disaffection leading to disobedience or deviance and loss of trusts in the profession and the organization in general. The chi-square results confirm this intrigues with values thus $\mathrm{x}^{2}(704)=1814.0, \rho=0.000$, this is less than 0.005 , affirming that there is a positive relationship between mobbing and display of work related deviance by employees in this context the EHO's. To avoid this unwanted behaviour in the work place mobbed behaviour exhibited by other cadre in the hospital and related environment should be neutralized and/or avoided to entrenched harmonious working relationship and health and medical settings in Nigeria.

\section{Conclusion}

Literatures abound as to the challenges posed by mobbing in most organizations and professions. This act of mobbing or bullying has a far reaching negative impacts and effects on the needed progress to meet up with the challenges of healthcare for all policy in Nigeria. Protection of the environment is to key to reducing the prevalence of diseases. The key actors to ensuring that this target is achieved are the EHO's, mobbing or bullying them directly or indirectly by both nurses, medical doctors and others speaks volume of the health disaster in the waiting. The biogeochemical activities of man on earth couple with anthropogenic behaviours of human beings on earth requires that EHO's stand as gatekeepers to the successful implementation of better health education, health promotion and health policy in Nigeria.

\section{Recommendation}

- The level of mobbed behaviour among the health workers is as a result of ignorance of the role each is supposed to play, therefore a collective and connective synchronization should be encourage.

- The training institutions of paramedical medical and medical professions should consider having a closely uniform curriculum integrates everybody to be separated only at the last two semesters of the professionals graduation.

Mobbed behaviour is termed in occupational safety as 'organizational misbehavior' and professional that display mobbed acts should reprimanded professionally as their act could lead to an estimable loss of lives in the society. 


\section{Compliance with ethical standards}

\section{Acknowledgments}

The authors wish acknowledge the support and encouragement of the three institutions, Kaduna State University, Kaduna Polytechnic, and Shehu Idris College of Health Technology all in Kaduna State Nigeria.

\section{Disclosure of conflict of interest}

The authors declare no conflict of interest

\section{Statement of informed consent}

Informed consent was obtained from all individual participants included in the study.

\section{References}

[1] Angeles Carnero M, Martínez B. and Sa'nchez-Mangas R. Mobbing and workers' health: empirical analysis for Spain, International Journal of Manpower. 2012; 33(3): 322-339.

[2] Anjum A, Yasmeen K, Yasmeen K. Bullying at work: A comprehensive definition and consequences based on an empirical study. Int. J. Hum. Resour. Stud. 2011; 1: 80-88.

[3] Antonio Ariza-Montes, Noel M Muniz, Maraí José Montero-Simó, Rafael Angel Araque-Padilla. Workplace Bullying among Healthcare Workers Int. J. Environ. Res. Public Health. 2013; 10: 3121-3139.

[4] Ayranci U, Yenilmez C, Balci Y, Kaptanoglu C. Identification of violence in Turkish health care settings. Journal of Interpersonal Violence. 2006; 21: 276-296.

[5] Aytac S, Bozkurt V, Bayram N, Yildiz S, Aytac M, Akinci SF, Bilgel N. Workplace violence: A study of Turkish workers. International Journal of Occupational Safety and Ergonomics. 2011; 17: 385-402.

[6] Bilgel N, Aytac S, Bayram N. Bullying in Turkish white-collar workers. Occupational Medicine. 2006; 56: $226-231$.

[7] Boyle M, Koritsas S, Coles J, Stanley J. A pilot study of workplace violence towards paramedics. Emergency Medicine Journal. 2007; 24: 760-763.

[8] Canbaz S, Dundar C, Dabak S, Sunter AT, Peksen Y, Cetinoglu EC. (2008). Violence towards workers in hospital emergency medical care units in Samsun: An epidemiological study. Ulus Travma Acil Cerrahi Derg. 2008; 14: 239-244.

[9] Carien W Alingh, Jeroen DH van Wijngaarden, Karina van de Voorde, Jaap Paauwe, Robbert Huijsman. Speaking up about patient safety concerns: the influence of safety management approaches and climate on nurses' willingness to speak up, BMJ Quality \& Safety. 2018; 28, 1, (39-48).

[10] Carol A Wong, Carol A Wong, Heather K Spence, Laschinger S. (2010). Authentic leadership and nurses' voice behaviour and perceptions of care quality, Journal of Nursing Management. Marie Giordano-Mulligan and Sarah Eckardt, Authentic Nurse Leadership Conceptual. 2010.

[11] Cowie H, Naylor P, Rivers I, Smith PK, Pereira B. Measuring workplace bullying. Aggression and Violent Behavior. 2002; 7: 33-51.

[12] Davenport N, Schwartz RD, Elliott GP. Mobbing: Emotional abuse in the American workplace. Ames, IA: Civil Society. 1999.

[13] Di Martino V. Workplace violence in the health sector: Country case studies. Brazil, Bulgaria, Lebanon, Portugal, South Africa, Thailand, and an additional Australian study (Synthesis report). 2002.

[14] Di Pasquale, V. (2002). Mobbing at the Workplace, Publication of the European Foundation for the Improvement of Living and working Condtions, (EUROFOUND), and the tripartite EU agency providing knowledge to assist in the development of better social, employment and work-related policies, Published 18 August, 2002 , information@eurofound.europa.eu.

[15] Einarsen S. Harassment and bullying at work: A review of the Scandinavian approach. Aggression and Violent Behavior. 2000; 5: 379-401. 
[16] Einarsen S, Hoel H, Zapf D, Cooper CL. The concept of bullying at work: The European tradition. In Einarsen, S., Hoel, H., Zapf, D., Cooper, C. (Eds.), Bullying and emotional abuse in the workplace: International perspectives in research and practice. 2003; 3-30.

[17] Einarsen S, Matthiesen S, Skogstad A. Bullying at work: Bullying, burnout and well-being among assistant nurses. Journal of Occupational Health \& Safety. 1998; 14: 563-568.

[18] Einarsen S, Skogstad A. Bullying at work: Epidemiological findings in public and private organisations. European Journal of Work and Organizational Psychology. 1996; 5: 185-201.

[19] El-Gilany AH, El-Wehady A, Amr M. Violence against primary health care workers in Al-Hassa, Saudi Arabia. Journal of Interpersonal Violence. 2010; 4: 716-734.

[20] Ekici, D., \& Beder, A. (2014). The Effects of Workplace Bullying on Physicians and Nurses. Australian Journal of Advanced Nursing, 31, 24-33.

[21] Ferrinho P, Biscaia A, Fronteira I, Craveiro I, Antunes AR, Conceição C, Flores I, Santos O. Patterns of perceptions of workplace violence in the Portuguese health care sector. Human Resources for Health. 2003; 1: 1-11.

[22] Figueiredo-Ferraz H, Gil-Monte PR, Olivares-Faúndez VE. Influence of mobbing (workplace bullying) on depressive symptoms: A longitudinal study among employees working with people with intellectual disabilities. Journal of Intellectual Disability Research. 2015; 59: 39-47.

[23] Framework, Nursing Administration Quarterly. 2019; 43(2): 164-174.

[24] Gascón S, Martinez-Jarreta B, Gonzalez-Andrade JF, Santed MA, Casalod Y, Rueda MA. Aggression towards health care workers in Spain: A multi-facility study to evaluate the distribution of a growing violence among professionals, health facilities, and departments. International Journal of Occupational and Environmental Health. 2009; 15: 30-36.

[25] Gumbus A, Lyons B. Workplace harassment: The social costs of bullying. J. Leadersh. Account. 2011 ; 8: 72-90.

[26] Hansen AM, Hogh A, Persson R, Karlson B, Gadre AH, Orbeak P. Bullying at work: Health outcomes, and physiological stress response. Journal of Psychosomatic Research. 2006; 60: 63-72.

[27] Heather K. Spence Laschinger, Carol Wong, Emily Read, Greta Cummings, Michael Leiter, Maura Macphee, Sandra Regan, Ann Rhéaume-Brüning, Judith Ritchie, Vanessa Burkoski, Doris Grinspun, Mary Ellen Gurnham, Sherri Huckstep, Lianne Jeffs, Sandra Macdonald-Rencz, Maurio Ruffolo, Judith Shamian, Angela Wolff, Carol YoungRitchie, Kevin Wood. Predictors of new graduate nurses' health over the first 4 years of practice, Nursing Open. 2018; 6(2): 245-259.

[28] Hogh A, Hoel H, Carneiro IG. Bullying and employee turnover among healthcare workers: a three-wave prospective study. Journal of Nursing Management. 2011; 19: 742-751.

[29] Kirel C. The supporting and risk reduction recommendations on mobbing management of the organizations. Anadolu University Journal of Social Sciences. 2007; 7: 317-334.

[30] Leon-Perez JM, Notelaers G, Arenas A, Munduate L, Francisco J, Medina FJ. Identifying victims of workplace bullying by integrating traditional estimation approaches into a latent class cluster model. Journal of Interpersonal Violence.n 2014; 29: 1155-1177.

[31] Metin Picakciefe, Gulcihan Acar, Zdehra Colak, Ibrahim Kilic. Article first published online: June 19, 2015.

[32] Myriam Tong, Rene Schwendimann, Franziska Zuniga. Mobbing among care workers in nursing homes: A crosssectional secondary analysis of the Swiss Nursing Homes Human Resources Project International journal of nursing studies 66. December 2016.

[33] Nachreiner N, Gerberich S, Ryan A, Mcgovern P. Minnesota nurses study: Perceptions of violence and the work environment. Industrial Health. 2007; 45: 672-678.

[34] Natasha Hawkins, Sarah Jeong, Tony Smith. New graduate registered nurses' exposure to negative workplace behaviour in the acute care setting: An integrative review, International Journal of Nursing Studies. 2019.

[35] Ortega A, Hogh A, Pejtersen JH. Prevalence of workplace bullying and risk groups: A representative population study. International Archives of Occupational and Environmental Health. 2009; 82: 417-426.

[36] Pedro MM, Sanchez MISS, Navarro MCS, Izquierdo MC. Workplace mobbing and effects on worker's health. The Spanish Journal of Psychology. 2008; 11: 219-227. 
[37] Picakciefe M, Akca S, Elibol A, Deveci A, Yilmaz N, Yilmaz UE. The analysis of violence against the nurses who are in employee status in Mugla State Hospital, Turkey. HealthMED. 2012; 6: 3626-3637.

[38] Razzaghian M, Shah A. Prevalence, antecedents, and effects of workplace bullying: A review. Afr. J. Bus. Manag. 2011; 5: 13419-13427.

[39] Sara Branch, Shery l Ramsay, Michelle Barke. Workplace Bullying, Mobbing and General Harassment: A Review, International Journal of Management Review,(IJMR). 2012; 15(3): 280-299.

[40] Teymourzadeh E, Rashidian A, Arab M, Akbari-Sari A, Hakimzadeh SM. Nurses exposure to workplace violence in a large teaching hospital in Iran. International Journal of Health Policy and Management. 2014; 3: 301-305.

[41] Vesile Erdogana, Aytolan Yildirim b. Healthcare professionals' exposure to mobbing behaviors and relation of mobbing with job satisfaction and organizational commitment. 9th International Conference on Theory and Application of Soft Computing, Computing with Words and Perception, ICSCCW 2017, 24-25 August 2017, Budapest, Hungary. 2017.

[42] Wen-Cheng SONG, Xiang-Qian ZHANG, Serena GIURA. Effects of Leaders' Positive/Negative Emotional Expression on Subordinates' Voice Behavior: Mediation Effect of Subordinates' Liking to Superiors, Revista de Cercetare si Interventie Sociala. 2019; 14(64): 167-180.

[43] Yildirim D, Yildirim A. Mobbing behaviours encountered by academic staff in university and their responses to them. Turkiye Klinikleri J Med Sci. 2010; 2: 559-570. 